\title{
What it means to succeed: Personal perceptions of career success held by senior managers
}

\author{
S. Visagie and E. Koekemoer* \\ School of Human Resource Sciences, WorkWell: Research Unit for Economic and Management Sciences \\ North-West University, Potchefstroom Campus, Private Bag X6001, Potchefstroom, 2520 \\ Eileen.Koekemoer@gmail.com
}

\begin{abstract}
This research describes the findings of a qualitative study which analyses how senior managers conceptualise and experience career success for themselves. A non-probability voluntary sample of 24 senior managers, using objective career success criteria, was selected from two international financial institutions located in Johannesburg. This research study entailed semi-structured in-depth interviews that were digitally voice recorded, transcribed verbatim, and analysed using content analysis. In exploring career success from the perspective of the individual (i.e. the senior manager) and not the organisation, the research attempts to fill the gap in the career literature. Findings demonstrate that although senior managers have general conceptualisations of what career success entail, they have unique personal meanings which they associate with their own career success (e.g. being associated with successful business brands, receiving feedback and recognition and adding value to the organisation). Senior managers also have specific goals set for their future in terms of careers (e.g. owning your own business venture, embracing new opportunities and investing in the community). Talent retention is particularly important among senior managers. Thus, in order to retain them as valuable employees, it is crucial to address and fulfil their career needs accordingly.
\end{abstract}

*To whom all correspondence should be addressed.

\section{Introduction}

The last two decades have been characterised by considerable changes in the career landscape where social, technological, economic and organisational changes have been the major drivers for these changes (Castells, 2000). The traditional career that is commonly associated with quick upwards progression within a single organisational hierarchy, has increasingly been replaced by a career without boundaries, a protean career. The protean career can be seen as rather disorganised and unpredictable and is commonly associated with lateral mobility across organisational boundaries (Arthur, Inkson \& Pringle, 1999; Arthur \& Rousseau, 1996; DeFillippi \& Arthur, 1996). Therefore it is evident that an evolution has taken place in the way careers and career success is defined. Miguel (1993) described the way career success has been conceptualised traditionally as the hierarchical advancement of an individual, accompanied by factors such as increase in pay, recognition and respect from others within a single organisation. A more modern definition of career success that reflects the change to a more protean type of career is that of Seibert and Kramer (2001). They view career success as constructive and psychological work-related outcomes or accomplishments that an individual achieves through his/her work experiences over time.

Career success encompasses both "extrinsic" objective success elements, such as pay, promotion and occupational level and status, and "intrinsic" subjective success elements, which are based on the individual's own subjective evaluation or perception of his/her career attainments, such as career satisfaction (Abele \& Spurk, 2008; Arnold \& Cohen, 2008; Dries, Pepermans \& Carlier, 2008; Heslin, 2003; 2005; Judge, Cable, Boudreau \& Bretz, 1995; Ng, Eby, Sorensen \& Feldman, 2005; Nicholson \& De WaalAndrews, 2005). Generally career researchers are in agreement that it is important to consider both aspects, as the meaning of a career can only be understood if different criteria are taken into account (Arthur, Khapova, \& Wilderdom, 2005; Heslin, 2005). It is therefore possible that objective career success can have an influence on how an individual subjectively experiences his/her career success. It is thus also conceivable that the individual's subjective experience of career success will have a direct influence on the development of his/her objective career success (Abele $\&$ Wiese, 2008).

Traditionally, career success has been defined in terms of objective measures such as promotions, compensation and management level positions. Research that was conducted on top executives' careers revealed that the movement up the corporate ladder usually happens through succession (Forbes \& Piercy, 1991). Succession or upward mobility in the organisational hierarchy is considered to symbolise success (Brett, 1997; Hall, 1996). A study conducted by Ng et al. (2005) supported the argument that individuals, who get promotions quite regularly, as well as regular salary increases, are those who are typically viewed to possess career success. Therefore societies and, even more specifically, organisations have a tendency to measure employees' career success according to these objective 
measures, especially when it comes to employees who are in management positions such as senior managers. Considering the nature of the present business environment, compensation still seems to be one of the major indicators of a successful management career (Eddleston, Baldridge \& Veiga, 2004). However, monetary compensation and promotions are not all that individuals seek from their careers (Gattiker \& Larwood, 1988; Korman, WittigBerman \& Lang, 1981; Sturges, 1999). Less substantial and less measurable subjective outcomes, such as a balance between personal life and working life and doing meaningful and purposeful work, are often more significant to individuals (Finegold \& Mohrman, 2001; Hall, 2002).

Therefore, in the era dominated by careers without boundaries, the consideration of subjective career success has become especially important, as researchers are of the belief that in the pursuit of highly diverse and unique career paths, it is individuals' sole responsibility to define and evaluate their own career success with reference to selfdefined aspirations, values, needs, standards and career stages (Arthur \& Rousseau, 1996; Betz \& Fitzgerald, 1987; Gattiker \& Larwood, 1986). Therefore, receiving pay increases and promotions that generally accompany senior managers' career does not necessarily mean that these senior managers feel successful. Different aspects need to be taken into consideration, especially their subjective perception of their own career success (Hall, 2002; Korman et al., 1981).

Career success has become a priority and is of interest both to individuals and organisations. Therefore in support of the foregoing, organisations pay much more attention to individuals' inner subjective definitions and experiences of success (as defined by their career orientations). This is done as a means of predicting these employees' organisational commitment, career satisfaction, motivation and performance. Such a focus has become a prominent trend within the business environment today (Coetzee, Bergh \& Schreuder, 2010; Havran, Visser \& Crous, 2003; Kanye \& Crous, 2007; Lumley, 2010). Organisations have also increasingly been paying attention to attracting, engaging and retaining their key employees (i.e. senior managers) as potential organisational leaders (Arthur et al., 2005; Baruch, 2004; Kock \& Burke, 2008).

If organisations endeavour to retain their valuable and key senior managers, they need to provide them with appropriate incentives and career paths that are in line with the career values, expectations and aspirations that underpin the career orientations of these employees (Coetzee \& Bergh, 2009; Järlström, 2000; Schein, 1996; Suutari \& Taka, 2004). Should organisations fail to create conditions where the work environment and the employee's inner subjective career orientation are compatible, the result may well be anxiety, stress, unhappiness, job and career dissatisfaction, and increased turnover (Coetzee \& Berg., 2009; Feldman \& Bolino, 1996; Jiang \& Klein, 2000; Jiang, Klein \& Balloun, 2001).

\section{Overview of literature on career success in South Africa}

Most of the studies that explore the concept of career success have been conducted across international boundaries (Arthur et al., 2005; Dries et al., 2008; Eby, Butts \& Lockwood, 2003; Eddleston et al., 2004; Heslin, 2003, 2005; Gunz \& Heslin, 2005; McDonald \& Hite, 2008; Ng et al., 2005). South African studies that explore the concept of career success are however rather limited, especially in terms of capturing subjective career success of senior managers who are generally perceived to have successful careers based on their income, status and occupational level (Ng et al., 2005). The majority of SA studies that have been conducted have been quantitative and focused mainly on the following: psychological factors in career situations as antecedents of women academics' success in their careers in South Africa (Riordan, 2007), career success of women academics in South Africa (Riordan \& Louw-Potgieter, 2011), psychological career resources as predictors of working adults' career anchors (Coetzee \& Bergh, 2009), and the influence of career orientations on subjective work experiences (Coetzee et al., 2010). In a qualitative study on career success done by Rowe and Crafford. (2003) the main focus was on the barriers of professional women's career advancement. Thus, most of the South African studies that have been done to explore the concept of career success, have been done on women, and not necessarily on senior managers with perceived objective career success. Considering the foregoing, the main objective in this study was to explore the conceptualisation and experience of career success among senior managers particularly focusing on how they define and attach personal meaning to career success.

\section{Methodology}

A qualitative research design with an exploratory approach was used to describe and explore senior managers' experience regarding their concept of career success. According to Denzin and Lincoln, (2003), researchers use qualitative research so that the focus is on observing and describing events as they occur within the specific research setting, with the sole purpose of capturing the full richness of participants' experiences of these events. The multidimensional nature of the concept of career success will require the use of the exploratory nature of qualitative research.

\section{Sampling}

A non-probability purposive, voluntary sample of 24 senior managers was drawn from two separate independent, internationally recognised financial institutions located in Johannesburg. 12 Senior managers were taken from one organisation and another 12 was taken from the second organisation.Due to the specific nature of the research topic, participants (i.e. senior managers) were selected based on objective career success criteria [i.e. pay, promotion, occupational level and status (Heslin, 2003)], and 
consequently specific inclusion criteria were established for participants to partake in the research. The inclusion criteria were set out as follows: (1) Employees who are in a senior management position or higher. (2) Employees with between five and ten years senior management experience. (3) Employees willing to participate in the research (willing to give written consent) after being informed about the purpose and procedures of the research. (4) Employees willing to be interviewed by the researcher. (5) Employees who are prepared to have their interview tape recorded by the researcher. Willing participants who adhered to the inclusion criteria were included in the research. The interviews were conducted until the researcher experienced data saturation. According to Bryman (2008) data saturation occurs when the emerging themes have been fully explored and no new insights are being generated from the interviews.

\section{Demographics}

The sample was representative mostly of English-speaking $(58,3 \%)$, male employees $(54,2 \%)$, between the ages of 35 and 55 years $(66,6 \%)$. Although the majority of the participants had children $(70,8 \%), 29,2 \%$ of the participants did not have children. More than of half of the participants were married or living with a partner, with their children still living at home $(62,5 \%)$. In terms of level of positions the sample included several management levels such as director level (29,2\%), executive level $(20,8 \%)$, managerial level $(20,8 \%)$, and senior management level $(16,8 \%)$, with a small number at partner $(4,2 \%)$, associate manager $(4,2 \%)$ and associate director level $(4,2 \%)$. A more or less equal distribution of total years of experience by employees was found, with $37,5 \%$ between $5-10$ years and $20,8 \%$ between 10-15 total years of experience. Also the years of experience in the industry were more or less equally distributed, with $37,5 \%$ between $10-15$ total years of experience and $29,2 \%$ between 5-10 total years of experience in the industry.

\section{Data collection and recording of data}

Semi-structured individual interviews were used to collect the data during the main investigation. According to Bryman (2008), semi-structured interviews typically refer to a context in which the researcher has prepared a series of questions in the form of an interview guide, but is able to vary the sequence of questions in response to what is seen as significant responses. During qualitative research, specifically interviews, three aspects of the physical environment are especially important to manage throughout the process, i.e. comfort, privacy and quietness (King \& Horrocks, 2010). Great care was therefore taken to ensure that the interview room was comfortable, temperate and quiet. The validity and success of the research outcomes is increased when participants are comfortable with the research process (Hess-Biber \& Leavy, 2004). Keeping this in mind, the researcher started the interviews by welcoming the participants and making them feel at ease. Thereafter an overview was provided of the context and the purpose of the research. During the interviews a series of standard questions were asked to all of the participants. The first question was, 'How do you view the overall concept of career success, or how would you conceptualise career success?' Considering the answer to this question, the second question was asked, 'What does career success mean to you personally?' Based on this question the third question was, 'Do you feel that you experience career success?' Whether interviewees answered yes or no, they were asked to explain their answer. The researcher utilised the communication skills and techniques that were gained during the qualitative training sessions, such as minimal verbal response, paraphrasing, reflection, clarification and summarising. This was done to encourage participants to elaborate on their thoughts, feelings, perspectives and experiences (Neuman, 2003). Before the interviews commenced, the use of a digital recorder for capturing data was explained and informed consent was obtained from all of the participants for the interviews. Each of the interviews was digitally recorded and the researcher also wrote comprehensive field notes after each interview was conducted. Field notes, also known as observation notes, are notes taken down immediately after the interview (De Vos, Strydom, Fouche \& Delport, 2005). The field notes therefore gave more depth and detail to the research findings by providing a written account of the researcher's experience through sight and hearing, and thought during the interview. After the interviews were completed, all of the recordings were transcribed verbatim and prepared for data analysis. Upholding confidentiality is critical and therefore related field notes, transcriptions and recordings were all labelled. This was done by a coding process that corresponded with the interview plan. Anonymity of the tapes' content, as well as of the transcription and observation notes, has been upheld for this purpose and are be stored in a secure place. This is necessary to guarantee that interviewees are not exposed or exploited by the researcher revealing personal data or the information they provided in confidentiality (Burns \& Grove, 1987; HessBiber \& Leavy, 2004). Neuman (2003) emphasises the importance of upholding the rights of the participants throughout the research process including their right to privacy, anonymity, fair treatment and protection from discomfort and harm.

\section{Data analysis}

After the collection and recording of data the verbatim transcripts were analysed using content analysis as a procedure. According to Flick (2009) content analysis is one of the established procedures for analysing textual material, particularly interviewing data. 'Content' refers to words, pictures, meanings, symbols and themes or any message that can be communicated (Mouton, 2001). This method facilitated the research process by making applicable and replicable assumptions from the text, while also considering the content and contextual meaning crucial to the research (Struwig \& Stead, 2001). To start the analysis, the researcher thoroughly read the transcribed interviews, several times, after which the responses of the participants were categorised into meaningful units that were presented 
as sentences or paragraphs. The units were then divided into clusters of main themes. Carefully analysing the main themes, smaller comparable sub-themes were recognised and summarised. These sub-themes were presented in the tables to follow, highlighting the research findings. The cocoder, considered as an expert in the field of qualitative research and in the relevant subject field, provided assistance throughout this process. According to HesseBiber and Leavy (2004) the co-coder or co-researcher's role is to contribute to the reliability and validity of the data, enhancing the overall quality of the data by collaborating with the researcher on identifying and establishing the themes and sub-themes.

\section{Strategies employed to ensure quality data}

In order to ensure quality data and validity and reliability in qualitative research, four principles were adhered to namely, credibility, transferability, dependability and conformability (Appleton, 1995; Bryman, 2008; De Vos et al., 2005; Lincoln \& Guba, 1985). To ensure that these principles were maintained throughout the research process, particular methods were employed. (1) The researcher received prepilot interview training to enhance her interviewing skills and confidence; following the training, the pilot interviews were conducted to review the interview guide or schedule and to provide the researcher with exposure to interviews and practice in interviewing. (2) Every step in the research process was illustrated comprehensively, and the underlying rationale of everything was explained; this was done to ensure that objectivity was maintained throughout the data collection process. (3) The researcher took detailed field notes after each of the interviews, in order to add detail and depth, and to improve the quality of the data. (4) An expert researcher was approached as an independent co-coder to assist the researcher in reviewing the main themes and subthemes that were captured and to corroborate agreement between researchers. (5) Finally, the results were discussed in a presentation of the research findings at a feedback session to management.

\section{Findings}

From the data analyses four main themes were identified and captured, where the first two themes reflected the participants' general conceptualisation of career success and also their own personal meaning which they attach to their career success. The third theme describes the transformation in perceptions that senior managers have towards their career success, while the last theme describes some of the more specific goals which senior managers set for themselves in terms of career success. These themes and their subsequent sub-themes are described below more thoroughly. For descriptive purposes the associated meaning and explanations are also presented in the following tables.
Theme 1: General conceptualisation of career success

This theme entails senior managers' general conceptualisation or view of career success. From the interviews it is clear that general conceptualisations of career success entail various different viewpoints and aspects which are presented in Table 1 below.

\section{Table 1: General conceptualisation of career success}

\begin{tabular}{|c|c|}
\hline Sub-themes & Associated meaning/Explanation \\
\hline $\begin{array}{l}\text { Achievement of } \\
\text { personal goals }\end{array}$ & $\begin{array}{l}\text { The achievement of personal goals, objectives } \\
\text { and aspirations; the establishment and } \\
\text { achievement of different goals; the } \\
\text { achievement of different personal goals for } \\
\text { different individuals. }\end{array}$ \\
\hline $\begin{array}{l}\text { Movement up the } \\
\text { corporate ladder }\end{array}$ & $\begin{array}{l}\text { Moving from a junior role into a more senior } \\
\text { role within the organisation; the achievement } \\
\text { of certain organisational levels; having } \\
\text { aspirations to move up in the organisational } \\
\text { ranks and then obtaining those } \\
\text { positions/ranks; progressing in organisational } \\
\text { ranks/positions; getting promoted to a higher } \\
\text { level in the organisation. }\end{array}$ \\
\hline $\begin{array}{l}\text { Exceeding } \\
\text { personal and } \\
\text { organisational } \\
\text { expectations }\end{array}$ & $\begin{array}{l}\text { Performing above and beyond organisational } \\
\text { and personal expectations; achieving beyond } \\
\text { of your set personal goals or aspirations; } \\
\text { exceeding organisational expectations in } \\
\text { terms of performance or productivity; } \\
\text { achieving more than is expected. }\end{array}$ \\
\hline $\begin{array}{l}\text { Contr } \\
\text { the or } \\
\text { (busil }\end{array}$ & $\begin{array}{l}\text { Contributing or adding value to the } \\
\text { organisation; contributing to the } \\
\text { organisation's success through achieving } \\
\text { organisation's goals; providing the } \\
\text { organisation with acceptable results. }\end{array}$ \\
\hline $\begin{array}{l}\text { Expe } \\
\text { satisf }\end{array}$ & $\begin{array}{l}\text { Gaining satisfaction from work; being happy } \\
\text { in and enjoying your work; experiencing job } \\
\text { satisfaction; experiencing personal fulfilment } \\
\text { and achieving life fulfilling success. }\end{array}$ \\
\hline $\begin{array}{l}\text { Gro } \\
\text { deve }\end{array}$ & $\begin{array}{l}\text { Having opportunities for further growth and } \\
\text { development; experiencing personal growth } \\
\text { and development; having opportunities for } \\
\text { career growth and personal growth within the } \\
\text { organisation. }\end{array}$ \\
\hline $\begin{array}{l}\text { Monetary } \\
\text { compensation }\end{array}$ & $\begin{array}{l}\text { Having an increase in monetary benefits such } \\
\text { as salary, bonuses, income and financial } \\
\text { resources; afforded opportunities to make } \\
\text { more money; provided opportunities to } \\
\text { become financially more independent. }\end{array}$ \\
\hline $\begin{array}{l}\text { Possessing } \\
\text { professional titles } \\
\text { or positions in the } \\
\text { organisations }\end{array}$ & $\begin{array}{l}\text { Possessing a prominent title or position within } \\
\text { the organisation (e.g. Managerial Director or } \\
\text { Chief Executive Officer (MD or CEO); } \\
\text { having the power to influence important } \\
\text { decisions; being at the forefront of the } \\
\text { organisation; having a widely acknowledged } \\
\text { reputation within the organisation. }\end{array}$ \\
\hline
\end{tabular}

From the interviews it became clear that participants held certain views of what career success entails in general. One of the most prominent general views held by the majority of participants was the achievement of personal goals. Participants mentioned that setting and achieving personal goals and aspirations were crucial to achieving career success. Whilst expressing this viewpoint, they also 
mentioned that individuals have different goals based on individual differences, and therefore career success would mean different things to different individuals. However, career success was not only conceptualised as the achievement of personal goals, but even more specifically, to exceed both personal and organisational expectations by performing above and beyond of what is expected. Participants stressed the importance of this by emphasising the contribution one must make to the organisation. In exceeding expectations, not only is the individual contributing to the organisation, but he/she is also adding value to the business. The following quotes illustrate some of these general views of career success:

"I think that career success is an individual thing so I think it's not something that you can get out of a textbook; therefore it depends on the individual and his/her aspirations". (Participant 2A)

I think if you just do what you're there for, or meant to do every day, you're not really going to succeed or grow in your position - so it's all about exceeding the expectations. That's probably the word I'm after. (Participant 10A)

Some of the participants mentioned that career success to them, meant moving up the corporate ladder and progressing from junior positions into more senior positions in the organisation, while other participants saw having the opportunities to grow both in their career and personally as more significant than merely progressing through the organisational levels. In addition, some participants also described the experience of satisfaction as important and argued that it's about being happy in your job and experiencing personal and job satisfaction. Interestingly, only a small number of the participants mentioned monetary compensation to be viewed in terms of career success; however it is still significant as participants referred to it in the context of being able to provide financially for their families.

\section{Theme 2: The personal meaning senior managers attach to their career success}

Although it became evident from the responses that each individual has a unique way of defining career success, general conceptualisations/views of career success do exist, however the specific meaning and views that senior managers attach to career success was prominent and somewhat different from the general conceptualisations. These are presented in Table 2 below.
Table 2: The personal meaning senior managers attach to career success

\begin{tabular}{|c|c|}
\hline Sub-themes & Associated meaning/Explanation \\
\hline $\begin{array}{l}\text { Being in a } \\
\text { leadership } \\
\text { position; } \\
\text { opportunity to } \\
\text { develop } \\
\text { employees }\end{array}$ & $\begin{array}{l}\text { Being responsible for the effective } \\
\text { management of employees; having the } \\
\text { opportunity to build leadership into the } \\
\text { organisation; having the autonomy to make } \\
\text { and influence decisions; setting a good } \\
\text { example for employees by behaving } \\
\text { responsibly/ethically; being involved in the } \\
\text { growth and development of employees; acting } \\
\text { as an advisor or enabler for employees. }\end{array}$ \\
\hline $\begin{array}{l}\text { Journey of } \\
\text { progression }\end{array}$ & $\begin{array}{l}\text { Experiencing career success as a rewarding } \\
\text { journey; seeing it as a long term vision/plan; } \\
\text { viewing it as an ongoing process of progress } \\
\text { towards achieving goals; not perceiving } \\
\text { career success as the ultimate state or } \\
\text { destination, but as a life-long journey. }\end{array}$ \\
\hline $\begin{array}{l}\text { Alignment of } \\
\text { personal goals } \\
\text { with } \\
\text { organisation's } \\
\text { goals }\end{array}$ & $\begin{array}{l}\text { Experiencing an alignment of personal goals } \\
\text { with the goals of the organisation; alignment } \\
\text { of personal expectations with the expectations } \\
\text { of the organisation; interaction between } \\
\text { personal objectives and business objectives; } \\
\text { balancing and integrating personal goals and } \\
\text { business goals. }\end{array}$ \\
\hline $\begin{array}{l}\text { Being known as } \\
\text { an expert in your } \\
\text { field of work }\end{array}$ & $\begin{array}{l}\text { Being the best in a particular sphere of } \\
\text { expertise; being considered as an important } \\
\text { source of information; having a reputable } \\
\text { status in your work environment and field; it's } \\
\text { more than a prominent title or position; } \\
\text { having a reputable status based on unique } \\
\text { skills and abilities. }\end{array}$ \\
\hline $\begin{array}{l}\text { Receiving } \\
\text { feedback and } \\
\text { recognition }\end{array}$ & $\begin{array}{l}\text { Receiving appraisals for good performance; } \\
\text { receiving acknowledgment for performance; } \\
\text { being shown gratitude for your efforts and } \\
\text { contribution; getting recognised for the } \\
\text { contribution you make or value you add to the } \\
\text { organisation. }\end{array}$ \\
\hline $\begin{array}{l}\text { Association with } \\
\text { successful brands }\end{array}$ & $\begin{array}{l}\text { Being able to work for or being associated } \\
\text { with 'blue chip companies, } 1 \text { working for } \\
\text { organisations that offer international } \\
\text { opportunities and exposure; being associated } \\
\text { with companies that have well established } \\
\text { brands. }\end{array}$ \\
\hline $\begin{array}{l}\text { Adding value to } \\
\text { the organisation }\end{array}$ & $\begin{array}{l}\text { Delivering work of a high standard; } \\
\text { contributing to the growth and success of the } \\
\text { organisation; making a meaningful } \\
\text { contribution to both the business imperatives } \\
\text { and the lives of employees; bringing new } \\
\text { skills to the organisation. }\end{array}$ \\
\hline $\begin{array}{l}\text { Personal growth/ } \\
\text { development and } \\
\text { growth through } \\
\text { progression }\end{array}$ & $\begin{array}{l}\text { Achievement of personal growth and } \\
\text { development through career growth and } \\
\text { advancement; acquiring new skills and } \\
\text { experience with each promotion; reaching } \\
\text { fullest potential through progression; } \\
\text { achieving personal maturation through career } \\
\text { advancement. }\end{array}$ \\
\hline $\begin{array}{l}\text { Satisfaction and } \\
\text { balance in life }\end{array}$ & $\begin{array}{l}\text { Gaining purpose and meaning from work; } \\
\text { experiencing job satisfaction and personal } \\
\text { fulfilment in work; doing a job that makes } \\
\text { you happy; being able to live a balanced life; } \\
\text { acknowledging the importance of striking a } \\
\text { balance between work and everyday life. }\end{array}$ \\
\hline
\end{tabular}




\begin{tabular}{l|l}
\hline & $\begin{array}{l}\text { Monetary compensation, such as salary, } \\
\text { increases or bonuses for performance; a } \\
\text { monetary recognition component for effort } \\
\text { and value; having a disposable income; } \\
\text { money provides a sense of job security and } \\
\text { stability. }\end{array}$ \\
\hline $\begin{array}{l}\text { Moving up the } \\
\text { corporate ladder } \\
\text { progression up } \\
\text { to certain level) }\end{array}$ & $\begin{array}{l}\text { Moving forward with your career up to the } \\
\text { point where you want to take it; progressing } \\
\text { hierarchically only to a specific level within } \\
\text { the organisation that's in line with your } \\
\text { unique personal goal or career goal; achieving }\end{array}$ \\
\hline $\begin{array}{l}\text { Achieving } \\
\text { personal goals in } \\
\text { set timeframe and } \\
\text { exceeding } \\
\text { expectations }\end{array}$ & $\begin{array}{l}\text { Achieving personal set goals within a certain } \\
\text { age/stage (timeframe) and in the process } \\
\text { achieving more than was set out to achieve; } \\
\text { achieving above and beyond what was set out } \\
\text { in the organisational timeframe. }\end{array}$ \\
\hline
\end{tabular}

${ }^{1}$ Blue chip companies: The term is commonly used in the context of general equities, which refers to large and credit-worthy companies. It also refers to companies that are known for their quality and the wide acceptance of their products and services. These companies are characterised by an ability to make large profits and pay

For the most, participants emphasised that success in their career is generally about achieving personal goals and exceeding expectations. However, for senior managers it is more about achieving goals in a set timeframe, in other words setting short term and long term goals to be achieved within a set timeframe. Short term goals would for example be set for the current year and long term goals would focus on the next three to five years. Closely related to this, participants referred to the importance of aligning personal goals with business goals before considering the actual achievement of goals.

Some of the participants discussed moving up the corporate ladder as the personal meaning they attach to career success, but added that this was true only up to a certain point or level. That point or level will differ depending on an individual's unique goal. The following example clearly explains this tendency:

"To me personally it would mean taking it to a senior management level and nothing higher, and that would be as far as I want to go. I think if I achieved that, I would feel successful, because that's something I've always aspired to get to". (Participant 5A)

In addition to moving up the corporate ladder, participants also referred to the personal and professional growth and development that follow as a result of progression and explained it as gaining new skills, knowledge and expertise with each promotion. Through continuous professional growth, senior managers are provided with the opportunity to become experts in their field of work. Being known as an expert in one's field was also cited by interviewees as proof of career success as illustrated in the statements below:

“Getting to manager level, suddenly it's not about one division. It's about being known across the firm and for example being known across the capital community and as an expert in your field. You have other individuals who contact you and say 'What do you think about this?' or 'What's your idea on that?' That to me is very indicative of being successful in your career". (Participant 1A)

"I think in a professional environment, that is one of the most coveted positions to have, and that is to be an expert in your field". (Participant 11A)

Senior managers also referred to the importance of feedback and recognition and suggested good appraisals on performance as being their most favourable feedback method to help determine their level of value and contribution to the organisation. However, this was less significant to them than being in a position of leadership, which emerged as one of the most significant aspects related to personal meaning that participants attached to career success. They discussed this in terms of not only being in a position where they could make and influence decisions. But even more importantly, they emphasised having the opportunity to be actively involved in the growth and development of their staff and making a difference to their lives on a daily basis. The statement below clearly reflects this viewpoint:

"I try every day to make a difference in the lives of the people I work with. I'm accountable for 13000 people and every day I say to myself: 'Am I leading them well, am I making a difference in their lives, am I setting a good example for them, and am I leading them with the right principles and values?” (Participant 3B)

A quite unique reflection that emerged was participants' preference to associate with successful brands. They discussed working for 'blue chip' companies as well as working for organisations that offer international opportunities and exposure, such as upgrading the marketability of their CV's and as a result enhancing their sense of success.

Interestingly, considering all of the above mentioned notions, senior managers summarised their personal meaning of career success as being a journey. They do not see career success as an ultimate state or a destination. They rather experienced it as a long term vision or journey of progression, where the journey does not only mean hierarchical progression. It also represents personal and professional growth and development that will continually take place until the end of their career. The example below clearly illustrates this argument:

"I feel that I do influence the company, I mean it's an ongoing evolution of course, it's never that you one day wake up and you think you're successful in your career. Every day you come to work and you build on your career, and you will continue doing so until the end of your career. So there's no point ever in time where you say that you've arrived or whatever you want to call it, and say I'm successful 
in my career, it's an ongoing process". (Participant 5B).

Considering that career success means different things to different individuals, it also became evident that in this journey (also referred to as a career path to career success) there is a level of personal and professional growth and development taking place in each individual on an ongoing basis. Therefore, a transformation of perceptions is prominent in the interviewees. Participants revealed that as they mature and grow older, their perceptions of their careers, and ultimately career success change from when they started out as young employees in an organisation. This is mainly due to the dynamics of their lives that change continually. This transformation process and the dynamics involved in it are discussed in more detail in theme three to follow.

\section{Theme 3: Transformation of perceptions}

This theme that has emerged from the interviews reflects how certain factors/influences play a role to transform the personal meaning that senior managers attach to career success. The participants described four interlinked categories as the main drivers that influenced the way they attached personal meaning to career success (stage of career lifecycle, age, job level, organisational and economic climate). Stage of career lifecycle emerged as the most significant cause that changed perceptions. According to participants as they progress through the different career lifecycles, their life and career change according to the specific career lifecycle in which they find themselves. As a consequence their priorities and values start to change, leading to a change in their perception of career success.

The second factor that was mentioned was age. Senior managers stated that as they moved through the different lifecycles of their career, they also grew older and became more mature. They mentioned that with maturity their value system changed, and as a result their viewpoint of what motivated them in terms of career success also changed. Job level emerged as the third factor. Participants explained that as they matured and moved through the different career lifecycles, they also attained different job levels. Seeing that there is an increase in responsibility and expectations related to that, it can cause a change in perception. For example, an individual can entertain a certain viewpoint of career success at a junior level and that viewpoint can change as he/she moves into more senior levels and up to top level. Some participants cited this transformation quite aptly:

"I've said growth and I've used that word growth and development in a broad sense, because I don't think my career success at this stage of my life and my career are the same as when I started out. When I was starting out, career success to me was reaching the top of the organisation, but that has since changed. I have another view and a far more realistic understanding of what motivates me, a better understanding of what motivates me than when I was younger. So with maturity, has come a change in what is important and what I prioritize in my career”. (Participant 9B)

The fourth factor that was considered as a driver for senior managers' transformation of perception is the organisational and economic climate. This factor is not closely or directly linked to the other factors, but it can have an influence during any stage of the career, or age or job level. These are elements in the work environment or economic environment that could cause changes in perception. One of the participants referred to the example of an economic recession where certain values are threatened and as a result leads to a changed perception, as illustrated by this statement:

"I think it depends on economic climates as well, because if you look at the recession we went through, I think peoples' value on money might have shifted a little bit in a sense that not only job security was important. When you look at your Maslow's hierarchy of needs, sometimes you take a step down, because you know other things are being threatened, and you can only move to the next level if those are actually satisfied at the level that you're currently in, so I think that leaves us where we are". (Participant 6A)

Although senior managers' perception of career success have changed throughout their careers they have defined their future success around the goals that they have set for themselves to achieve in the future, something that they would measure as their pinnacle of success. These goals are explored in Theme 4 .

\section{Theme 4: Future goals of senior managers}

Even though senior managers' goals are time and future orientated (e.g. short, medium and long term), it became clear senior managers define their own personal success in terms of goals or aspirations that they set for themselves. Not only are these goals or aspirations different for each individual, but they will also change over the course of their career. The following table summarises some of these specific goals that senior managers mentioned. 
Table 3: Future goals of senior managers

\begin{tabular}{|c|c|}
\hline Sub-themes & Associated meaning/Explanation \\
\hline $\begin{array}{l}\text { Owning a personal } \\
\text { business venture }\end{array}$ & $\begin{array}{l}\text { Opening and running own business; being } \\
\text { the owner of your own business; working } \\
\text { for yourself and not for an organisation or } \\
\text { employer. }\end{array}$ \\
\hline $\begin{array}{l}\text { Moving up the } \\
\text { corporate ladder }\end{array}$ & $\begin{array}{l}\text { Moving up to the next level in the } \\
\text { organisation; obtaining a higher desired } \\
\text { position in the organisation; hierarchical } \\
\text { progression in the organisation; } \\
\text { performing manager's role in the future; } \\
\text { having a more advanced role with added } \\
\text { responsibility. }\end{array}$ \\
\hline $\begin{array}{l}\text { Expanding current } \\
\text { role }\end{array}$ & $\begin{array}{l}\text { Lateral expansion of current role; growing } \\
\text { the scope of your practice; diversify job } \\
\text { specifications of current role; becoming a } \\
\text { specialist or expert, rather than a } \\
\text { generalist. }\end{array}$ \\
\hline $\begin{array}{l}\text { Embracing } \\
\text { opportunities }\end{array}$ & $\begin{array}{l}\text { Having the opportunity to explore different } \\
\text { arenas; being open minded about available } \\
\text { opportunities; prepared and equipped for } \\
\text { emergent opportunities; open to new } \\
\text { challenges; having opportunities for } \\
\text { relocation or international exposure. }\end{array}$ \\
\hline $\begin{array}{l}\text { Achieving } \\
\text { goals }\end{array}$ & $\begin{array}{l}\text { Delivering on the goals and exceeding } \\
\text { expectations set by the business within } \\
\text { certain timeframe; contributing to building } \\
\text { success of organisation by fulfilling your } \\
\text { role; exceeding on key performance } \\
\text { indicators set for a financial year; } \\
\text { achieving mandates set by management of } \\
\text { the organisation. }\end{array}$ \\
\hline $\begin{array}{l}\text { Investing in } \\
\text { community }\end{array}$ & $\begin{array}{l}\text { Making a meaningful contribution to the } \\
\text { community; adding value to society; } \\
\text { investing in social responsibility; giving } \\
\text { back to the community; creating } \\
\text { sustainability in the community, such as } \\
\text { job creation. }\end{array}$ \\
\hline
\end{tabular}

One of the most significant goals senior managers set for themselves to define their own future success was to be the owner of a personal business venture. They saw creating and running their own business, where one does not have to work for an employer and can regulate one's own working hours, as the ultimate pinnacle of success. Some participants, however, still valued the role they play within the organisation, and therefore defined their future success within the organisational framework. While some senior managers attached value to hierarchical progression, others expressed a desire for progression more in a lateral sense. This last group explained it as expanding or specialising their role, and in a sense focusing on becoming experts in their field of work. A number of participants defined their future success in terms of the success of the business, meaning that their focus is on attaining and exceeding the goals, expectations and mandates that were set out for the financial year. Interestingly, senior managers also revealed that one of the most important future goals for them was to invest in the community and to contribute in building sustainability within society. In practice this could mean being involved in job creation or being involved in non- profit organisations that focus on the welfare of the community.

The statements below reflect some of these goals:

"I think going forward, I think it probably has got to be more of a lateral progression than upwards progression, so the next thing for me is to make sure that I grow in the scope of what I do in many contexts so that I can multiply the value that I add to the business (Participant 10B)

"You never know what opportunities might come out now, but I'd also love to have my own business with my own psychologists and psychometrists, reporting to me. I'd be happy with that". (Participant 3A)

"The fact is that whatever the future holds for me, I need to make sure that I'm prepared for it, I need to constantly equip myself, and develop myself to be ready for those opportunities that emerge". (Participant 6B)

\section{Discussion}

Definitions of career success are characterised as multidimensional, dynamic and individualistic, which reestablishes the need to understand the diverse ways in which the concept is being formulated and experienced (McDonald $\&$ Hite, 2008). It is crucial for human resource development practitioners and researchers in organisations to explore not only individuals' conceptualisation of career success but more specifically senior managers' perception of the concept. As a result, the general objective of this study was to investigate the nature of senior managers' unique conceptualisations and experiences of career success. This was reflected in four main themes.

The four themes are: the general conceptualisation of career success; senior managers' personal meaning associated with their career success; transformation of perceptions and future goals of senior managers. From the findings it became evident that senior managers' conceptualisations of career success are multi-dimensional, individualistic and dynamic. This was also found to be true in a study done by McDonald and Hite (2008) where the nature of individuals' conceptualisations were found to be multifaceted, diverse and fluid, and something that people designed and developed in their own minds, without any clear boundaries.

Due to careers that have become less definable, senior managers appear to view career success to be the achievement of personal goals and attach very specific personal meanings to career success. This is typical of the nature of a career without boundaries where the individual is more concerned with independent rather than organisational goals (Arthur et al,. 2005; Cappelli, 1999). Senior managers' other more common general conceptualisations of career success revolved around moving up the corporate 
ladder, experiencing satisfaction, possessing professional titles or positions, and monetary compensation. These conceptualisations seem to be still in line with the traditional, objective world view of career success. This is supported by $\mathrm{Ng}$ et al. (2005) who argue that the individuals who are often promoted and granted salary increases are those who are typically viewed to possess career success. As a result societies, and more specifically organisations, tend to evaluate their employees' career success according to objective external measures. Even though in the present business environment it is evident that compensation still remains one of the main indicators of a successful management career (Eddleston et al., 2004), pay and promotions are not all that people seek from their career (Gattiker \& Larwood, 1988; Korman et al., 1981; Sturges, 1999).

This was clearly reflected by the personal meaning senior managers attached to career success when stating that to them career success was not merely about money, fancy titles or status. It was mainly about being in a meaningful and fulfilling role and position where they constantly influenced other people's lives, and consequently contributed and added value to the organisation. According to Finegold and Mohrman. (2001) and Hall (2002), individuals want to derive a sense of meaning and purpose from their work. Therefore it was clear that senior managers' general conceptualisation captured mostly the objective side of career success while the personal meaning that senior managers derived from their careers brought in the more subjective side of career success. This is supported by Heslin's (2003) argument that objective career success criteria alone are insufficient in terms of exploring and explaining all of the essential facets that are related to the career success construct. In fact, when focusing exclusively on individuals' objective career success, it could lead to incompatibility of their career goals and strategies with their personal values and beliefs (Callanan, 2003). This was evident in the research, as senior managers saw the alignment of their personal goals with those of the organisation as significant in attaining personal meaning and concomitant career success.

Additional interesting and unique personal meanings that senior managers held with regard to their career success included to be associated with successful brands. This happened, senior managers explained, when they worked for well-established brand companies, which enhanced the marketability of their CVs. Another personal meaning mentioned by senior managers was the concept that career success was seen as a journey of progression rather than an end state or destination. These perceptions seem to be unique and more subjective and could not be substantiated by previous research.

Very representative of this journey of progression was senior managers' maturation and movement through different stages of a career lifecycle and job levels. During this process their priorities and values changed, which caused them to experience transformations in their perceptions of career success. This is supported by most theorists who are in agreement that the mid-life career stage is characterised by a time where "the dream" of career success that was formulated during young adulthood, is critically re-evaluated, therefore leading to a transformation in the perception of career success (Erikson, 1963; Schein, 1978). However, senior managers also referred to the influence of the organisational and economic climate in transforming perceptions. They explained how something like a recession could cause values to change, leading to changes in people's perception on career success. A study conducted by Heslin (2005) found organisational change to be a driver in the transformation of perceptions on career success.

Related to the personal meaning senior managers attached to career success, they also discussed their visions for success in terms of their futures. Some senior managers saw their future career success within the organisation as a hierarchical progression or a lateral progression: moving up into the next available position or moving into a more specialised role, and achieving the business goals that were set to be achieved within a set time-frame. Others saw their future success outside their current organisations: owning a personal business venture and investing in the community by creating sustainable jobs. Some senior managers considered their future goals such as owning their own business as the pinnacle of their success. This theme emerged as a unique theme in exploring senior managers' subjective future career success and it could therefore not be substantiated by previous literature.

\section{Conclusion}

Conclusions aim to determine and explore the role the organisation plays in enabling its senior managers to attain career success. The organisation has a collaborative role to play in the careers of employees, and even more particularly those of senior managers. To facilitate career success organisations need to ensure that they provide an environment that is conducive to employees' careers. This implies an environment where employees feel contented and fulfilled; also where they feel they can grow and thrive by being provided with the appropriate challenges, opportunities and career development measures and where they feel that they are contributing and adding value to the organisation by making a difference in other people's lives. The necessity of such an environment that is conducive to pursuing careers is also supported by Gilbreath (2008). Considering the high prevalence of potential to experience turnover intention, the organisation has an extremely important and unique role to play in retaining their key individuals (senior managers). This can be done by reevaluating senior managers' career goals and aspirations, as well as the career paths and opportunities within the organisation available to them.

\section{Limitations and suggestions for future research}

Even though the research made significant contributions to the understanding of career success for senior managers, 
some important limitations are worth mentioning. One of the major limitations concerns the number of participants. The population sample was too small to allow for generalisation of results to the whole financial private sector. The themes that were recognised and explored in this study could therefore possibly be only representative of the particular organisations and their cultures. Broadening the sample by including more financial organisations could have provided more definite insights into senior managers' conceptualisation and experience of career success working in the financial sector. Consequently special care should be taken when generalising the research findings. Considering cross-cultural differences in terms of the conceptualisation and experience of career success ( $\mathrm{Ng}$ et al., 2010), another limitation would be that the sample was not language representative in terms of the different cultural groups; the majority of the sample was English-speaking. Therefore it would be recommended for future research on career success and employees' conceptualisation and experience of career success to use a sample of employees from across different cultures, especially considering the languages related to the specific cultural groups found in South Africa. Employees from across different sectors and industries should also be included in the sample. This will provide a much bigger scope in which employees' conceptualisation and experience of career success within the diverse South African context would be understood.

Based on the research findings, it is recommended that organisations recognise senior managers' personal viewpoint on career success and help to create a situation where there is compatibility between senior managers' personal perception of career success and the organisation's perception of career success. Considering the important value that senior managers add to an organisation, organisations need to have good relationships with their key role players (senior mangers). This can be done by evaluating senior managers' future goals and making sure there are available opportunities for them within the organisation.

\section{References}

Abele, A.E. \& Spurk, D. 2008. 'The longitudinal impact of self-efficacy and career goals on objective and subjective career success', Journal of Vocational Behavior, 74: 53-62.

Abele, A.E. \& Wiese, B. 2008. 'The nomological network of self-management strategies and career success', Journal of Occupational and Organizational Psychology, 73: 490-497.

Appleton, J. V. 1995. 'Analysing qualitative interview data: Addressing issues of validity and reliability', Journal of Advanced Nursing, 22(1): 278-308.

Arnold, J. \& Cohen, L. 2008. The psychology of careers in industrial and organizational settings: A critical but appreciative analysis. Vol. 23. New York, NY: Wiley.
Arthur, M.B., Inkson, D. \& Pringle, J. 1999. The new careers: Individual action and economic change. London: Sage.

Arthur, M.B., Khapova, S.N. \& Wilderdom, C.P.M. 2005. 'Career success in a boundaryless career world', Journal of Organisational Behaviour, 26: 177-202.

Arthur, M.B. \& Rousseau, D.M. 1996. The boundaryless career: A new employment principle for a new organizational era. New York, NY: Oxford University Press.

Baruch, Y. 2004. 'Transforming careers: From linear to multi-directional career paths', Career Development International, 9(1): 58-73.

Betz, N. \& Fitzgerald, L. 1987. The career psychology of women. Orlando, FL: Academic Press.

Brett, J.M. 1997. 'Family, sex, and career advancement' In Greenhaus, J. \& Parasuraman, S. (eds.). Integrating work and family: Challenges and choices for a changing world. Westport, CT: Quorum Books.

Bryman, A. 2008. Social research methods. $3^{\text {rd }}$ Edition. Oxford, NY: Oxford University Press, Inc.

Burns, N. \& Grove, S.K. 1987. The practice of nursing research. Philadelphia, PA: WB Saunders Press.

Callanan, G.A. 2003. 'What price career success', Career Development International, 8(3): 126-133.

Cappelli, P. 1999. The new deal at work: Managing the market-driven workforce. Boston, MA: Harvard Business School Press.

Castells, M. 2000. 'Materials for an exploratory theory of the networked society', British Journal of Sociology, 51(2): 5-24.

Coetzee, M. \& Bergh, Z. 2009. 'Psychological career resources and subjective work experiences of working adults: An exploratory study', SA Business Review, 13(2): 131 .

Coetzee, M., Bergh, Z. \& Schreuder, D. 2010. 'The influence of career orientations on subjective work experiences', SA Journal of Human Resource Management, 8(1): 1-13.

Coetzee, M. \& De Villiers, M.A. 2010. 'Sources of job stress, work engagement and career orientations of employees in a South African financial institution', SA Business Review, 14 (1): 27-57.

Coetzee, M. \& Schreuder, A.M.G. 2009. 'Using the Career Orientations Inventory (COI) for measuring career orientations in the South African organisational context', $S A$ Journal of Industrial Psychology, 35(1): 1-13. 
De Fillippi, R.J. \& Arthur, M.B. 1996. 'Boundaryless contexts and careers: A competency-based perspective.' In Arthur, M.B. \& Rousseau, D.M. (eds.). The boundaryless career: A new employment principle for a new organizational era. New York, NY: Oxford University Press.

Denzin, N.K. \& Lincoln, Y.S. 2003. Collecting and interpreting qualitative materials. $2^{\text {nd }}$ Edition. Thousand Oaks, CA: Sage Publications.

De Vos, A.S., Strydom, H., Fouche, C.B. \& Delport, C.S. L. 2005. Research at Grass roots: For the social sciences and human service professions. $5^{\text {th }}$ Edition. Pretoria: Van Schaik Publishers.

Dries, N., Pepermans, R. \& Carlier, O. 2008. 'Career success: Constructing a multidimensional model', Journal of Vocational Behaviour, 7: 254-267.

Eby, L.T., Butts, M. \& Lockwood, A. 2003. 'Predictors of success in the era of the boundaryless career', Journal of Organisational Behaviour, 24: 689-708.

Eddleston, K.A., Baldridge, D.C. \& Veiga, J.F. 2004. 'Toward modelling the predictors of managerial career success: Does gender matter?' Journal of Managerial Psychology, 19(4): 360-385.

Erikson, E.H. 1963. Identity: Youth and crisis. London: Faber \& Faber.

Feldman, D.C. \& Bolino, M.C. 1996. 'Careers within careers: Reconceptualising the nature of career anchors and their consequences', Human Resource Management Review, 6(2): 89-112.

Finegold, D. \& Mohrman, S.A. 2001. 'What do employees really want? The perception vs the reality.' Paper presented at the annual meeting of the World Economic Forum, Davos, Switzerland.

Flick, U. 2009. An introduction to qualitative research. $4^{\text {th }}$ Edition. London: Sage Publications.

Forbes, J.B. \& Piercy, J.E. 1991. Corporate mobility and paths to the top. New York, NY: Quorum Books.

Gattiker, U.E. \& Larwood, L. 1986. 'Subjective career success: A study of managers and support personnel', Journal of Business and Psychology, 1: 78-94.

Gattiker, U.E. \& Larwood, L. 1988. 'Predictors for managers' career mobility, success, and satisfaction', Human Relations, 41(8): 569-591.

Gilbreath, G. 2008. 'Creating career-conducive organisations: A primary intervention', Advances in Developing Human Resources, 10(8): 8-31.
Gunz, H.P. \& Heslin, P.A. 2005. 'Reconceptualizing career success', Journal of Organizational Behavior, 26: 105-111.

Hall, D.T. 1996. 'Protean careers of the 21st century', Academy of Management Executive, 10(4): 8-16.

Hall, D.T. 2002. Careers in and out of organisations. Thousand Oaks, CA: Sage Publications.

Havran, H., Visser, D. \& Crous, F. 2003. 'The internal career orientations of permanent and contracting information technology staff', SA Journal of Industrial Psychology, 29(3): 53-60.

Heslin, P.A. 2003. 'Self and other referent criteria of career success', Journal of Career Assessment, 11: 262-286.

Heslin, P.A. 2005. 'Conceptualising and evaluating career success', Journal of Organisational Behaviour, 26: 113-136.

Hesse-Biber, S.N. \& Leavy, P. 2004. Approaches to qualitative research: A reader on theory and practice. USA: Oxford University Press.

Järlström, M. 2000. 'Personality preferences and career expectations of Finnish business students', Career Development International, 5(3): 144-154.

Jiang, J.J. \& Klein, G. 2000. 'Supervisor support and career anchor impact on the career satisfaction of the entry-level information systems professionals', Journal of Management Information Systems, 16(3): 219-240.

Jiang, J.J., Klein, G. \& Balloun, J.L. 2001. 'The joint impact of internal and external career anchors on entry-level IS career satisfaction', Information and Management, 39: 3139.

Judge, T.A., Boudreau, J.W. \& Bretz, R.D. 1994. 'Job and life attitudes of male executives', Journal of Applied Psychology, 79: 767-782.

Judge, T.A., Cable, D.M., Boudreau, J.W. \& Bretz, R.D. 1995. 'An empirical investigation of the predictors of executive career success', Personnel Psychology, 48(3): 485-519.

Kanye, B. \& Crous, F. 2007. 'Graduate interns' experiences: A career success orientations approach', SA Journal of Industrial Psychology, 33(3): 84-93.

King, E.C. \& Horrocks, C. 2010. Interviews in qualitative research. London: Sage Publications Ltd.

Kock, R. \& Burke, M. 2008. 'Managing talent in the South African Public Service'. [online]URL: http://www.entrepreneur.com/tradejournals/article/1923520 88 2.html. 
Korman, AK., Wittig-Berman, U. \& Lang, D. 1981. 'Career success and personal failure: Alienation in professionals and managers', Academy of Management Journal, 24(2): 342-360.

Lincoln, Y.S. \& Guba, E.G. 1985. Naturalistic inquiry. London: Sage.

Lumley, L. 2010. 'The relationship between career anchors, job satisfaction and organisational commitment'. Unpublished masters dissertation, Department of Industrial and Organisational Psychology, University of South Africa, Pretoria, South Africa.

McDonald, K.S. \& Hite, L.M. 2008. 'The next generation of career success: Implications for HRD', Advances in Developing Human Resources, 10(86): 86-103.

Miguel, M.M. 1993. 'Individual definitions of career success: At odds with organisational and social definitions'. Doctoral dissertation, University of North Carolina. Dissertation Abstract International, 1995 54(4): 1456.

Mouton, J. 2001. How to succeed in your master's and doctoral studies: A South African guide and resource book. Pretoria: Van Schaik Publishers.

Neuman, W.L. 2003. Social research methods: Qualitative and quantitative approaches. USA: Allyn \& Bacon.

Ng, T.W.H., Eby, L.T., Sorensen, K.L. \& Feldman, D.C. 2005. 'Predictors of objective and subjective career success: A meta-analysis', Personnel Psychology, 58(2): 367-408.

Ng, T.W.H. \& Feldman, D.C. 2010. 'Human capital and objective indicators of career success: The mediating effects of cognitive ability and conscientiousness', Journal of Occupational and Organizational Psychology, 83: 207-235.

Nicholson, N. \& De Waal-Andrews, W. 2005. 'Playing to win: Biological imperatives, self-regulation, and trade-offs in the game of career success', Journal of Organizational Behaviour, 26: 137-154.

Riordan, S. 2007. 'Career psychology factors as antecedents of career success of women academics in South Africa'. Doctoral dissertation. Cape Town: University of Cape Town.

Riordan, S. \& Louw-Potgieter, J. 2011. 'Career success of women academics in South Africa', South African Journal of Psychology, 41(2): 157-172.

Rowe, T. \& Crafford, A. 2003. 'A study of barriers to career advancement for professional women in investment banking', South African Journal of Human Resource Management, 1(2): 21-27.

Schein, E.H. 1978. Career dynamics: Matching individual and organisational needs. Reading, MA: Addison-Wesley.
Schein, E.H. 1996. 'Career anchors revisited: Implications for career development in the 21 st century', Academy of Management Executive, 1: 80-88.

Seibert, S.E. \& Kramer, M.L. 2001. 'The five-factor model of personality and career success', Journal of Vocational Behaviour, 58: 1-21.

Struwig, F.W. \& Stead, G.B. 2001. Planning, designing and reporting research. South Africa: Maskew Miller Longman.

Sturges, J. 1999. 'What it means to succeed: Personal conceptions of career success held by male and female managers at different ages', British Journal of Management, 10: $239-252$.

Suutari, V. \& Taka, M. 2004. 'Career anchors of managers with global careers', Journal of Management Development, 23(9): 833-847.

\section{Author's Note}

The material described in this article is based on work supported by the National Research Foundation under the reference number, TTK20110823000025405.

Any opinion, findings and conclusions, or recommendations expresses in this material are those of the author(s) and therefore the NRF does not accept any liability in this regard thereto. 